\title{
Petrographic Study of Silica-rich Continental Carbonates from São José de ITABORAÍ BASIN (BRAZIL
}

\author{
Brenda da Silva Valente ${ }^{1}$, Gustavo do Couto Ramos Pereira ${ }^{2 *}$, Emiliano Castro Oliveira ${ }^{3}$ and Sergio \\ BERGAMASCHI $^{1}$
}

1 Universidade do Estado do Rio de Janeiro, Faculdade de Geologia, Departamento de Estratigrafia e Paleontologia. Av. São Francisco Xavier, 524, sala 2020A, Maracanã. 20550-013 Rio de Janeiro, RJ, Brazil. brendasvalente@gmail.com, sergiobe@uerj.br

2 The University of Manchester, School of Earth and Environmental Sciences. Oxford Road, Williamson Building, office 1.73. M13 9PL, Manchester, United Kingdom. gustavo.pereira@postgrad.manchester.ac.uk

3 Departamento de Ciencias do Mar, Universidade Federal de São Paulo, Avenida Saldanha da Gama 89, Santos, 11030-400, Brazil.emiliano.unifesp@gmail.com

*Corresponding Author, sergiobe@uerj.br

Received on 2 December 2017

Received in revised form on 3 February 2018

Accepted on 5 February 2018

Editor: Egberto Pereira, Universidade do Estado do Rio de Janeiro, Brazil
SCREENED BY

$\sqrt{\text { TiThenticate }}$

Citation:

Valente, B.S., Pereira, G.C.R., Oliveira, E.C., Bergamaschi, S., 2017. Petrographic study of silica-rich continental carbonates from São José de Itaboraí Basin (Brazil). Journal of Sedimentary Environments, 2 (4): 319328.

\section{Abstract}

São José de Itaboraí Basin (SJIB) is located in the city of Itaboraí, Rio de Janeiro State (Brazil), at about $60 \mathrm{~km}$ from the Rio de Janeiro city. Despite the small size area, about 1.5 $\mathrm{km}^{2}$, this basin represents an important source of scientific knowledge, due to the occurrence of banded carbonates and exuberant fossil assemblages. In the last decade, following the discovery of massive carbonates in South Atlantic Ocean, this basin has attracted the attention due to the presence of continental carbonates, in the form of travertines which are included the Itaboraí Formation. The SJIB carbonate rocks have been recognized as possible analogues of the pre-salt reservoir rocks or at least, similar in their depositional processes. The SJIB travertines were submitted to some diagenetic influence due to the presence of silica rich fluids, similar to that found in pre-salt carbonates. The present research aims to perform a petrographic analysis regarding the silica-rich travertine facies, and to recognize textures and structures in order to provide a better understanding of the relationship between

silica and carbonate. The deposits associated with silica are easily characterized by their reddish/brown coloring and their higher resistance, due to the presence of iron oxide and silica replacing the carbonate. In some extreme cases can occur the complete substitution of the carbonate fabric generating silex materials. The relationship between silica and iron oxide/carbonate allowed the development of different structures as the banding formation, probably due to mineralogical and rheological differences during recrystallization. In some regions where the diagenetic process was more intense it could be noticed a complete replacement of the primary carbonate material. While, in other cases, the diagenesis preserved structures and past textures, such as iron oxide mouldic features.

Keywords: Sedimentology. Continental Carbonates. Travertine. Sinter. Petrography. 


\section{Introduction}

The discovery of the Tupi Field, the massive carbonate of South Atlantic Ocean hydrocarbon reservoirs (PreSalt), as lacustrine deposits underlain by massive stratified evaporites (Carminatti et al. 2008), have gathered attention and fostered studies and has become one of the most important discoveries of the industry during the last decades. In Brazil, only few examples of continental carbonates are known, and only in Rio de Janeiro State, the deposits from Itaboraí Formation, in the São José de Itaboraí Basin (SJIB) were recognized. These rocks can be considered continental thermal carbonate or travertine as first described in the 30 `s as banded carbonates by Leinz (1938). The Itaboraí Formation was deposited in the SJIB, located in Rio de Janeiro State, at a distance of about 60 $\mathrm{km}$ from the Rio de Janeiro city.

Continental carbonates are any type of rock formed by precipitation of calcium carbonate and calcium/magnesium strictly under the influence of continental waters according to Alonso-Zarza and Tanner (2009). Continental carbonates are separated informally in travertines, precipitated from hot springs, tufas, precipitated from low temperature sources, such as lakes and rivers (meteogene travertine), and speleothems, precipitated from low to high temperature water in caves or karst fracture systems (Pentecost, 1995, Ford and Pedley, 1996).

According to Riccomini et al. (1989, 2004) São José de Itaboraí Basin (SJIB) formation is associated to the beginning (Paleogene $~ 59-57 \mathrm{Ma}$ ) of the Continental Rift of Southeastern Brazil (CRSB) settlement. The CRSB is formed by a series of Cenozoic grabens in southeast Brazil, from Paraná until north of Rio de Janeiro State, coinciding with the extension of Serra do Mar and, partially, the Serra da Mantiqueira with structural orientation parallel to these mountains and the Atlantic coast as well.

The extensional regime imposed to the area and the occurrence of magmatic intrusions events associated to the intensive hydrothermal activity in the basins of Volta Redonda and São José de Itaboraí (Sant'Anna and Riccomini, 2008) resulted in the increased concentrations of calcium, bicarbonate ions and silica in superficial and underground waters in these basins. The high bicarbonate content, allowed the formation of thermal carbonate (travertine) and associated to these deposits the precipitation of silica and amorphous silica (chalcedony) took place (Sant'Anna et. al., 2004). According to Wright and Barnett (2015), the silicification is a common feature in some pre-salt facies due to a lake formation environment enriched in dissolved silica fluids. Travertine occurs mainly as fine laminated deposits, crystalline crust deposits and veins in the context of hot spring carbonates.
In areas near the border of the basin, carbonate breccias with silica deposits can be found.

Since the discovery of the basin in the late 1920s, it was noticed the potential of SJIB for kaolin and carbonate exploration. The extractive activities lasted for 50 years, and the material provided from the basin for the construction of Maracanã Stadium, Presidente Costa e Silva Bridge (Rio-Niteroi Bridge) and many more buildings in Rio de Janeiro city. The total thickness of the deposit at the beginning of the extraction was estimated at about $70 \mathrm{~m}$ (Brito, 1989). The exploration has been ceased since the early 80's and due to the removal of the exploration apparatus an artificial lake was formed in the center of the basin.

In December of 1995, the Paleontological Park of Itaboraí was created (Bergqvist et al., 2009) due to its importance, both from the scientific perspective and the historical development of Rio de Janeiro State and as a form of protection and preservation of the basin, as well as to foster studies, research and public visitation.

\subsection{The main goals}

The aim of this work was to study the travertines from Itaboraí Basin, focusing mainly the facies presenting precipitation of silica, and to contribute to the understanding of its relationship with the carbonate deposits and the hydrothermal system activity.

\section{Study Area}

The São José de Itaboraí Basin, more commonly known as Itaboraí Basin, is a small depression in Rio de Janeiro State (Fig. 1). It is recognized as one of the smallest Brazilian sedimentary basins. It is an elliptic shaped structure with $\approx 1,400 \mathrm{~km}^{2}$, even so, it is regarded as an important source of information considering its rich fossiliferous assemblage, ankaramitic dykes and the presence of continental carbonate facies.

The geological context of the basin is correlated to the Guanabara Graben in the tectonic context of Ribeira folded belt (Heilbron et al., 1995, Martins et al., 2004). During the Cenozoic, as a response to the tectonic rifting between Brazil and Africa, the settlement of the Continental Rift of Southeastern Brazil (CRSB) was established. The CRSB includes a series of Cenozoic grabens in southeastern Brazil running from Paraná to the north of Rio de Janeiro State. Its structural trends orientation is parallel to the escarpments of Serra do Mar and Serra da Mantiqueira mountains and the Atlantic coast (Riccomini et al., 1989; Ferrari, 2001).

The distensive events resulted in larger-scale grabens, such as the Guanabara Graben. Smaller-scale hemigrabens are associated to those process, as well. 

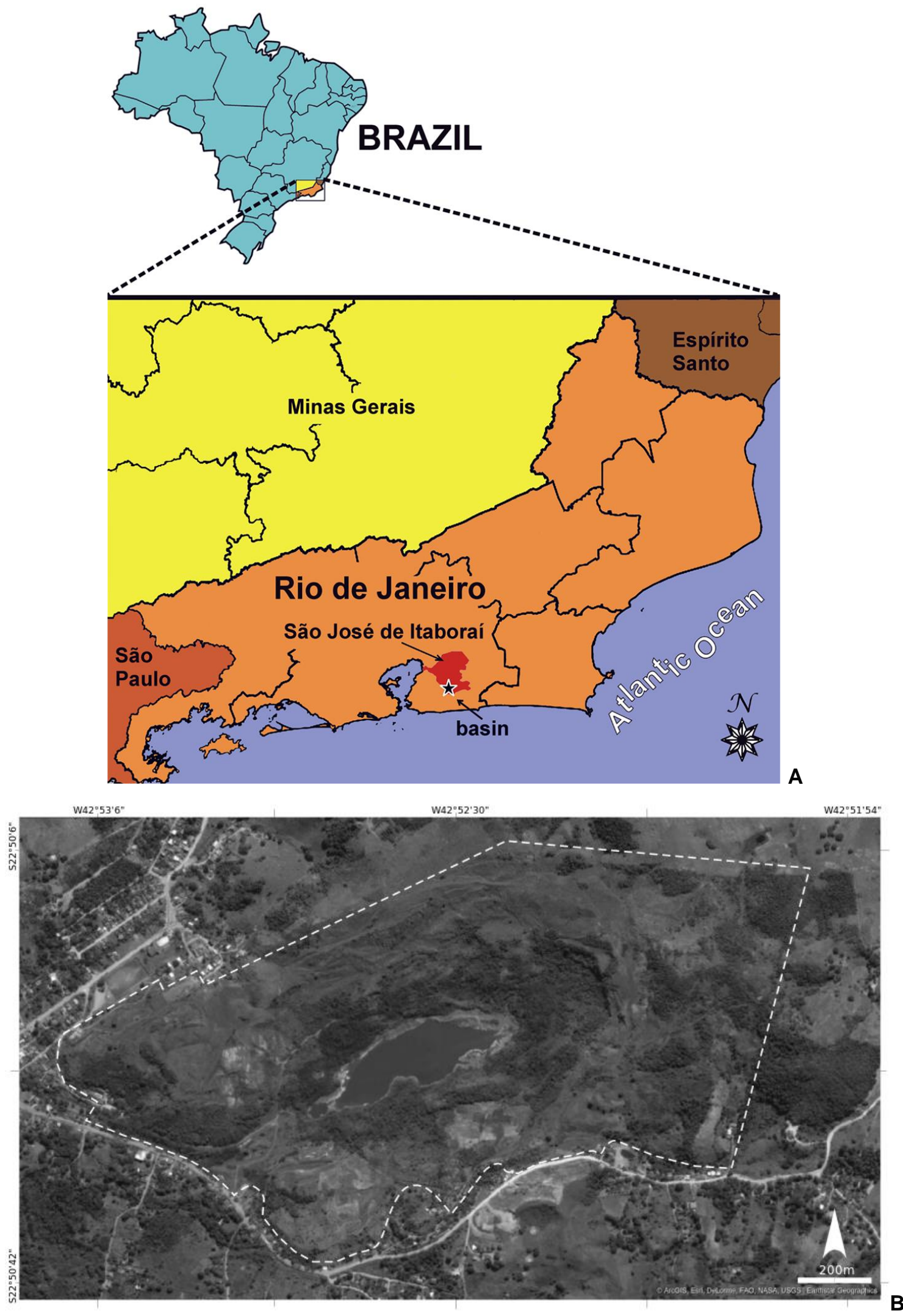

Fig. 1. Satellite image of the Itaboraí Sedimentary Basin, marked by the boundaries of the Paleontological Park of São José de ItaboraíItaboraí City - RJ. Adapted from Kellner et al., 2014 (A) and Pereira et al., 2016 (B). 
The Itaboraí Basin hemi-graben is one of them, which is conditioned by St. José (SW-NE) normal fault. The hydrothermal activity registered in SJIB is assigned, in association with the ankaramitic lava flow from lower Eocene (Riccomini et al., 2005), to same extensional processes that originated the basin.

The basement consists of amphibolite to granulite gneiss interlaid with lenses of marble and calc-silicate rock from the Neoproterozoic (Sant'Anna et al., 2004; Bergqvist et al., 2009) and the ankaramitic dykes (Riccomini et al., 2005).

The SJIB sediments are represented by lake, marsh, travertine and alluvial deposits, comprising the Itaboraí Formation, which are subdivided into three sedimentary sequences and an ankaramitic magmatic flow (Fig. 2). The oldest sequence (S1) from Upper Paleocene is deposited on the basement, comprises three facies formed by thermal springs carbonates, deposited within a lacustrine environment and contains fossils of weeds, gastropods, reptiles and mammals (Bergqvist et al., 2009).

The middle sequence (S2), deposited onto S1 fissures and dissolution cavities, is characterized by marls and carbonate breccias (Fig. 2) from alluvial environments associated with lake environments, also from the upper Paleocene, and bears a high concentration of vertebrate fossils, including mammals, reptiles and birds, invertebrates and macrophytes (Bergqvist et al., 2009). In the central-north border of SJIB, above S1 and S2 sequences, there is an ankaramitic basaltic flow fed by a dike (10 $\mathrm{m}$ thick and $150 \mathrm{~m}$ long) that cuts the basin. Carbonized macrophyte and gastropod fossil remains are identified in the deposits belonging to sequences S1 and S2 below the dyke (Bergqvist et al., 2009).

The upper sequence (S3), consists of rudite sediments and alluvial conglomerates, which is dated from the upper Eocene/lower Oligocene, and contains plant, mammal and reptile fossils (Bergqvist et al., 2009).

The Itaboraí Formation is dated from the Paleocene due to their vertebrate fossils content (Sant'Anna et al., 2004, Bergqvist et al., 2009) and the magmatic basaltic rock flow dated of 52.6 Ma (Riccomini et al., 2005).

\section{Material and Methods}

The field work was carried out in the SJIB in order to recognize and identify the continental deposits and the relationship with silica. Sedimentological studies were taken in the outcrop near of the active border of the basin, right below the panoramic deck (22\%50'28.36"s; $42^{\circ} 52^{\prime} 44.98^{\prime}$ 'W). Samples were collected and selected for the preparation of thin sections. Fourteen thin sections were made in the Laboratory of Preparation of the Samples (LGPA), by laboratory technicians. The preparation is divided into three operations:

1. Sanding and paste the sample on the slide.

2. Cutting and thinning (the sample is cut with the aid of an abrasive cutting machine accuracy, and further suffers wear using abrasive (silicon carbide powder fine granulometry) is obtained until the desired thickness of the rock),

3. Sanding or cover with cover slip (performed on polishing cloths combined with diamond pastes and high viscosity lubricant).

The samples were analyzed using a petrographic microscope in the Stratigraphy and Paleontology Department of the Universidade do Estado do Rio de Janeiro. The silica/carbonate interaction and the depositional and diagenetic characteristics were analyzed.

\section{Results and discussion}

Pereira et al. (2016) described the deposits associated with silica as carbonate enriched in silica, a facies formed due to carbonate thermal precipitation which suffered some differentiation processes becoming enriched in silica fluids.

These deposits represent facies variation of the bedded carbonate deposited in the basin. It presents a reddishbrown color and a higher hardness due to the presence of silica. The silica precipitation for instance, led to increase in porosity as noted as millimetric to decimetric vugs pores. In some extreme cases, it could lead to the complete substitution of the carbonate fabric generating silex deposits, and by this occluding much of the rock porosity. The processes from the silica deposition in the present studies were associated with Syn and Posdepositional precipitation of travertine, associated mainly with tectonic pulses.

The thermal deposits are widespread through the entire basin. The outcrops located in the vicinity of the active border of the basin are related to this "exogenous" depositing fluid. In Fig. $3 \mathrm{~A}$ the carbonates show some differentiation, as the top presents typical travertine banded carbonates, while towards the bottom the carbonates display a different texture and have reddish color patterns associated to iron oxide silicified deposits.

In some situations, the thermal deposits are strongly affected by the silicification process. In these cases, the travertine bands become so silicified that the original depositional characteristics are obliterated by the microcrystalline quartz substitution, as well as by the interconnected decimetric pores, as seen macroscopically in Fig. 3B. The influence of silica rich fluids as an important driver for the precipitation and/or diagenesis of thermal deposits can be observed with greater intensity near active faults. 


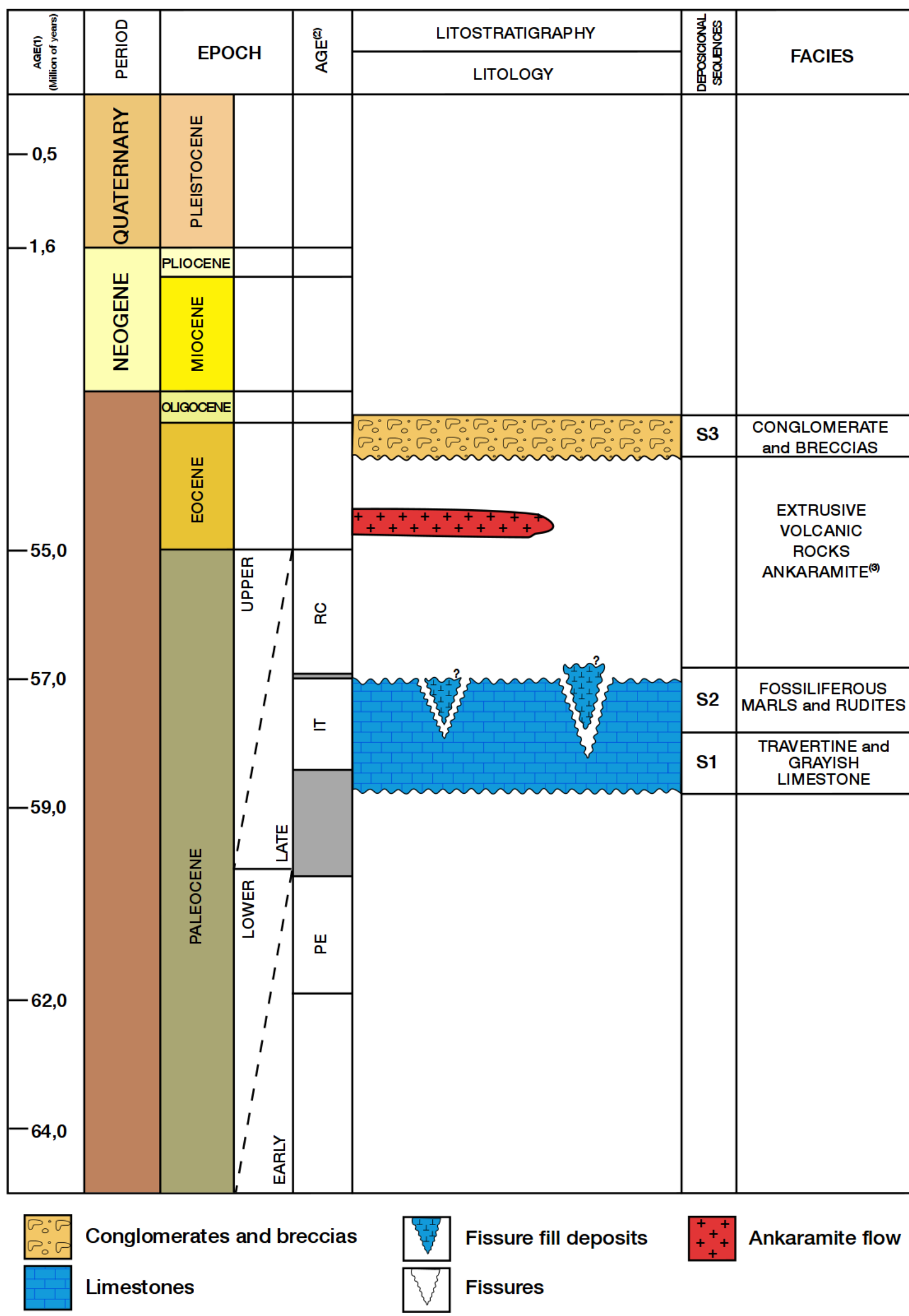

Fig. 2. Chronostratigraphic column of the Itaboraí Basin (Bergqvist et al., 2008). 


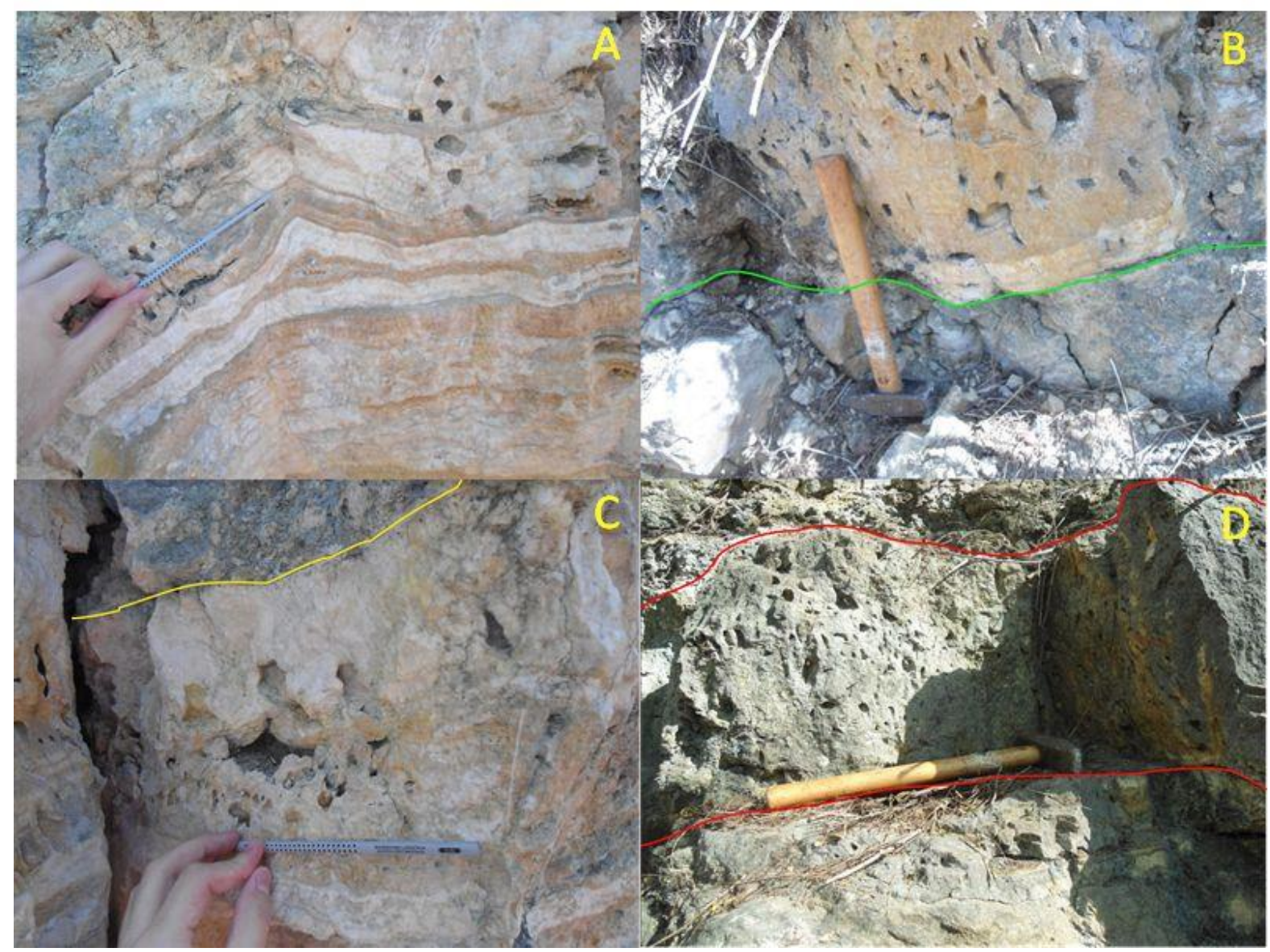

Fig. 3. The Facies Association of silica deposits. (A) Banded travertine at top and enriched silica carbonate at the bottom. (B) At the bottom conglomeratic deposits separating the vuggy silicified carbonates (C) Alluvial deposits at top, and banded carbonate presenting some decimetric vugs at bottom. (D) Banded carbonates enriched in silica interleaved by alluvial deposits.

However, even in areas not so close of the active faults, it is still possible to note the influence of these fluids through the formation of vug cavities (Fig. 3C). The silica enriched carbonates are commonly found interlayed with conglomerate carbonates (Fig. 3D). These latter deposits are associated mostly with alluvial paleoenvironments.

The presence of these silicified carbonates enables a better understanding regarding the genesis of the precipitating fluids in the basin and the relationship with alluvial deposits and the travertine deposition itself. According to Pereira et al. (2016), the presence of conglomerates associated with travertine deposits on the active border of the basin suggests the occurrence of episodes of major tectonic activity associated with less active ones, while travertine deposits genesis should be related to the reactivation of faults.

The petrographic analysis indicated a strong diagenetic activity and it was possible to correlate the presence of the silica to this process other than syn-depositional primary silica (Pereira et al., 2016). The main observed features were the formation of banding, vugs, preservation and/or obliteration of structure, as well as the deposition of such minerals as iron oxide, microcrystalline silica and chalcedony.

The relationship between silica and iron oxide/carbonate led the formation of different structures as the banding formation, for example, probably due to mineralogic and rheologic differences during recrystallization. In some regions, where the diagenetic process was more intense, it could be noticed a complete replacement of the primary carbonated material and the presence of veins cutting the old fabric (Fig. 4A). In other situations, the diagenesis preserved structures and preterit textures as iron oxide mouldic features, according to Pereira et al. (2016).

Gas bubbles features has been recognized and associated with the presence of veins, both occurring mostly due to sub-aerial exposition, indicating multiple phases of the rocks "silicification" (Pereira, 2015).

Shrubby structures represented a common association within the studied carbonates. This texture was frequently observed, replaced by iron oxide and amorphous silica, preserving the depositional texture. 


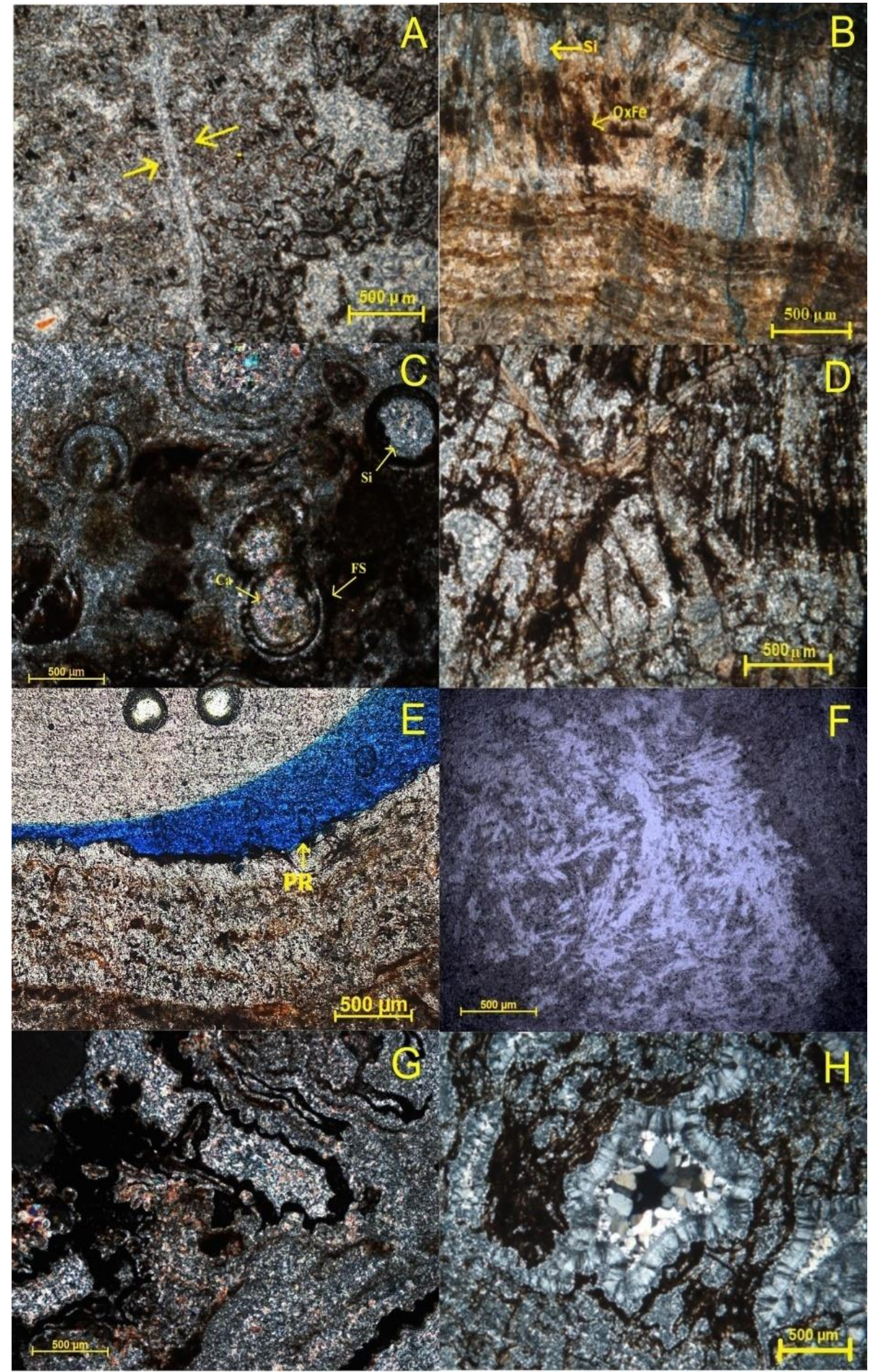

Fig. 4. Photomicrograph of the carbonate enriched in silica facies. (A) Thin Section ITA 26C. The arrows indicated quartz microveins, cutting the sample. (B) Thin section ITA 30A. Shrub syn-depositional feature partially replaced by iron oxide (OxFe) and micro crystalline silica (Si). (C) Thin section ITA 26A. Pisoids (FS) preserved due to the almost total calcite replacement by micro crystalline silica (Si). Syn-depositional carbonate can be found in the interior of the fossil preserved registry (Ca). (D) Thin section ITA 28. Interference between syn- and pos- depositinal textures. (E) Thin section ITA 06B. Secondary porosity (PR) formed by a vug cavity. (F) Thin section ITA 26A. Dissolution of the microcrystalline silica, followed by iron oxide precipitation and $(\mathrm{G})$ Thin section ITA 42. Microcrystalline chalcedony, indicating silica-rich fluid have sufficient time to grow such crystals. $(\mathrm{H})$ Thin Section ITA 26, presenting elongated pore with concentric silica precipitation. 
Figure 4B shows a preserved shrub texture modified due to diagenetic processes, which formed some iron oxide rich bands, while the carbonate fabric was mostly replaced by microcrystalline silica. Pisoids were also found replaced by iron oxide and silica, although they are less recurrent structures than shrubs (Fig. 4C).

Many factors from sedimentary conditions to diagenetic modifiers, influence the shrub morphologies and their fabrics. The primary controls are related to the dominant processes during precipitation, hence the actual discussion on precipitation rate and biotic versus abiotic precipitation. For continental carbonates it is possible to consider the occurrence of microbial mediation versus evaporation and degassing. Fast precipitation should have resulted of an abiotic dominant process, while 'less fast' precipitation allows microbes to have a higher influence or even control on the fabrics (Dupraz et al., 2009; Claes et al., 2017).

In the thin section of the sample ITA28 is possible to observe the obliteration of syn-depositional structures (carbonate substitution), post-depositional (diagenetic chalcedony) and the presence of shrub texture, both occurring as result of iron oxide substitution (Fig 4D).

Diagenesis can cause both porosity obstruction by cementation or enhance the porosity, in most cases by dissolution. Processes of dissolution in travertine have been widely documented due to meteoric diagenesis (Pentecost, 2005). The dissolution can form vugs which are typically coated by silica crystals, leading to secondary porosity (Fig. 4E). In addition to the carbonates dissolution, the precipitation of silica crystals can be noticed in the Fig. 4F, followed by iron oxide enriched material precipitation. The development of such features is associated with the liberation of gases during diagenesis (Gandin and Capezzuoli, 2014). The mentioned textures are usually linked to regions where the tectonic activity is intense, such as fault borders. The comprehensive understanding of these mechanisms is an important matter for petrophysical analysis purposes.

The silica occurs mostly as microcrystalline crystals. It is not possible to observe quartz grains in the thin section, especially in zones where carbonate replacement was more intense and lead to complete or almost complete substitution. Chalcedony, a cryptocrystalline form of silica, is commonly found as microcrystals building grains due to recrystallization (Fig. 4G). Its formation indicates that the grain had more time for develop and the making fluid was flowing slower through the rock (Fig. 4H).

According to Anders and Wiltschko (1994), the faults and the fracture network can have an important role channeling and circulating the hydrothermal fluids. Micro and macro fractures influence the ascending pathways of hydrothermal water, and the precipitation rate
RESEARCH PAPER

significantly increases near the fault planes. Also, these hydrothermal fluids (and specially $\mathrm{CO}_{2}$ ) associated with volcanism, during different rifting phases, contribute significantly to the precipitation of carbonates, but also to the alteration of the volcanic rocks (Teboul et al., 2017). The alkaline suites and bodies in the SJIB adjacent areas, as well as, the ankaramite dyke should have actively participated in the enrichment in calcium of the fluids (Pereira et al., 2016).

A similar model is envisioned also for the Pre-Salt deposits since the largely volcanic catchment lithology in the South Atlantic suggests that the lakes received silicarich inflows from the streams and springs. Silica precipitation should be linked to a rise in lake levels (pluvial events) and a lowering of the $\mathrm{pH}$ (Wright, 2012) which should have lead to silica precipitation and to the development of chert nodules in association with anoxic lake bottom mudstones (Ceraldi and Green, 2016). Therefore, the petrographic studies represent an important challenge in order to understand the dynamic of precipitation phases in South Atlantic reservoir.

The petrographic analysis made possible to understand the following order of processes. The first stage of the silica registry should have been the deposition of the primary carbonates through the direct precipitation from enriched silica fluids, followed by iron oxide percolation and final rich-silica percolating fluid. The Itaboraí deposits have been through intense diagenetic processes where it was recognized a wide range of textures and structures. Structures such as vugs, iron oxide deposition, microcrystalline silica and chalcedony, partial to complete replacement of the carbonate by the silica and the occurrence of veins filled with silica are the main tracers to the diagenetic history in the basin. Even so, some observed features in thin sections were described as having being related to the deposition process, such as banding, shrubs and some primary features that were able to be recognized despite partial obliteration or preservation due to diagenesis activity.

Previous rock isotopic analysis performed by Sant anna et al. (2004) and Pereira et al. (2016) provide non-conclusive isotopic results regarding the origin of the deposits and the diagenetic evolution of the Itaborai deposits. The isotopic data points to a tufa signature, despite the travertine-like texture and deposits and the evidences of high temperature features found in the basin as the ankaramyte dike, silica and chalcedony precipitation associated to the border of the basin, as well as, some facies affected by temperature influence.

A comprehensive isotopic study based on a microanalysis of each facies is recommended, aiming to sample both highly diagenetic altered regions and unaffected regions. The applied method would provide the isotopic signature of each type of cement and the respective facies, 
enabling to compare and trace the diagenetic evolution properly.

\section{Conclusion}

This study enabled to have a better understanding of the diagenetic processes during the basin development and regarding the faults reactivations which led ultimately to the silicatic fluids flowing and precipitating in the system. Diagenetic textures were recognized, as well, the succession of diagenetic phases recorded in the analyzed outcrops of Itaborai Basin.

The results suggest the following sequence for the diagenetic processes: firstly, the deposition of the primary carbonate, followed by a set of percolating iron oxide enriched fluids and lastly a set of silica-rich fluids leading to the silica chalcedony and micro-crystalline deposition.

\section{Acknowledgment}

The authors are grateful to FAPERJ for financial support (graduation grant) during the period April 2014 to March 2015.

\section{References}

Alonso-Zarza, A.M., Tanner, L.H. (Eds), 2009. Carbonates in continental settings: geochemistry, diagenesis and applications. Developments in Sedimentology 62, Amsterdam: Elsevier. 336 p. ISBN: 9780444535276

Anders, M.H., Wiltschko, D.V., 1994. Microfracturing, paleostress and the growth of faults. Journal of Structural Geology 16(6), 795-815. https://doi.org/10.1016/01918141(94)90146-5

Bergqvist, L.P., Mansur, K., Rodrigues, M.A., RodriguesFrancisco, B.H., Perez, R.A.R., Beltrão, M.C.M.C., 2009. Bacia São José de Itaboraí, RJ: berço dos mamíferos no Brasil. In: Winge, M. (Ed.) et al., Sítios Geológicos e Paleontológicos do Brasil, SIGEP 123, 413-431.

Brito, I.M., 1989. Geologia e paleontologia da bacia calcária de São José de Itaboraí, Estado do Rio de Janeiro, Brasil. Anuário do Instituto de Geociências, UFRJ, 12, 56-64.

Capezzuoli, E., Gandin, A., Pedley, M., 2014. Decoding tufa and travertine (fresh water carbonates) in the sedimentary record: the state of the art. Sedimentology 61(1), 1-21. https://doi.org/10.1111/Sed.12075

Carminatti, M., Wolff, B., Gamboa, L., 2008. New exploratory frontiers in brazil: Proceedings of the $19^{\text {th }}$ World Petroleum Congress, Madrid, Spain, June 29-July 3, 2008, 11 p.

Ceraldi, T.S., Green, D., 2016. Evolution of the South Atlantic lacustrine deposits in response to early cretaceous rifting, subsidence and lake hydrology. Geological Society, London, Special Publications 438. https:/ / doi.org/10.1144/SP438.10

Claes, H., Erthal, M.M., Soete, J., Ozkul, M., Swennen, R., 2017. Shrub and pore type classification: petrography of travertine shrubs from the Ballik-Belevi area (Denizli, SW Turkey). Quaternary International 437, 147-163. http://dx.doi.org/10.1016/J.Quaint.2016.11.002
Dupraz, C., Reid, R.P., Braissant, O., Decho, A.W., Norman, R.S., Visscher, P.T., 2009. processes of carbonate precipitation in modern microbial mats. Earth-Science Reviews 96 (3), 141-162. http://dx.doi.org/10.1016/ J.Earscirev.2008.10.005

Ferrari, A.L., 2001. Evolução tectônica do graben da Guanabara. PhD Thesis, Instituto de Geociências da Universidade de São Paulo, 412 p.

Ford, T.D., Pedley, H.M., 1996. A review of tufa and travertine deposits of the world. Earth-Science Reviews 41(3), 117175. https://doi.org/10.1016/S0012-8252(96)00030-X

Gandin, A., Capezzuoli, E., 2014. Travertine: distinctive depositional fabrics of carbonates from thermal spring systems. Sedimentology 61(1), 264-290. https://doi.org/10.1111/Sed.12087

Heilbron, M., Valeriano, C.M., Valladares, C.S., Machado, N., 1995. A Orogênese Brasiliana no segmento central da Faixa Ribeira, Brasil. Revista Brasileira de Geociências 25 (4), 249266.

Kellner, A.W.A., Pinheiro, A.E.P., Campos, D.A., 2014. A new Sebecid from the Paleogene of Brazil and the Crocodyliform radiation after the K-Pg Boundary. Plos ONE 9(1), E81386. https://doi.org/10.1371/Journal.Pone.0081386

Leinz, V., 1938. Os calcáreos de São José de Niterói, Estado do Rio de Janeiro. Mineração e Metalurgia 3(15), 153-155.

Martins, V.T.S., Teixeira, W., Noce, C.M., Pedrosa-Soares, A.C., 2004. Sr and Nd characteristics of Brasiliano/Pan-African granitoid plutons of the Araçuaí Orogen, Southeastern Brazil: Tectonic Implications. Gondwana Research 7 (1), 75-89. https://doi.org/10.1016/s1342-937x(05)70307-5

Pentecost, A., 1995. The Quaternary travertine deposits of Europe and Asia Minor. Quaternary Science Reviews 14 (10), 1005-1028. https://doi.org/10.1016/02773791(95)00101-8

Pentecost, A., 2005. Travertine. Springer Science and Business Media. ISBN 978-1-4020-3606-4.

Pereira, G.C.R., 2015. Estudo sedimentológico e petrográfico dos carbonatos continentais da Bacia de Itaboraí. MsD Thesis, Universidade do Estado do Rio de Janeiro.

Pereira, G.C.R., Oliveira, E.C., Bergamaschi, S., 2017. Continental carbonates from Itaboraí Formation, Southeast, Brazil. Quaternary International 437, 199-211. http://dx.doi.org/10.1016/j.quaint.2016.12.006

Riccomini, C., Sant'anna, L.G., Ferrari, A.L., 2004. Evolução geológica do Rift Continental do Sudeste do Brasil. In: Mantesso Neto V., Bartorelli, A., Carneiro, C.D.R., Brito Neves, B. (Eds.), Geologia do Continente Sul-Americano: evolução da obra de Fernando Flávio Marques de Almeida, Editora Beca, p. 383-405.

Riccomini, C., Pellogia, A.U.G., Saloni, J.C.L., Kohnke, M.W., Figueira, R.M., 1989. Neotectonic activity in the Serra do Mar Rift System (Southeastern Brazil). Journal of South American Earth Science 2 (2), 191-197.

Riccomini, C., Velásquez, V.F., Gomes, C.B., 2005. Tectonic controls of the mesozoic and cenozoic alkaline magmatism in central-southeastern Brazilian Platform. In: ComimChiaramonti, P., Gomes, C. B. (Eds.), Mesozoic to Cenozoic alkaline magmatism in the Brazilian Platform, São Paulo, Edusp/Fapesp, p. 31-56.

Sant'anna, L.G., Riccomini, C., Rodrigues-Francisco, B.H., Sial, 
A.N., Carvalho, M.D., Moura, C.A.V., 2004. The Paleocene travertine system of the Itaboraí Basin, Southeastern Brazil. Journal of South American Earth Sciences18(1), 11-25. https://doi.org/10.1016/J.Jsames.2004.08.005

Sant'Anna, L.G., Riccomini, C., 2001. Cimentação hidrotermal em depósitos sedimentares paleogênicos do rift continental do Sudeste do Brasil: mineralogia e relações tectônicas. Revista Brasileira de Geociências 31(2), 231-240.

Teboul, P.-A., Kluska, J.-M., Marty, N.C.M., Debure, M.M., Durlet, C., Virgone, A., Gaucher, E.C., 2017. Volcanic rock alterations of the Kwanza Basin, offshore Angola - Insights from an integrated petrological, geochemical and numerical approach. Marine and Petroleum Geology 80, 394-411. https://doi.org/10.1016/J.Marpetgeo.2016.12.020.

Wright, V.P., Barnett, A.J., 2015. An abiotic model for the development of textures in some South Atlantic early Cretaceous lacustrine carbonates. Geological Society, London, Special Publications, 418, 209-219. https://doi.org/10.1144/SP418.3

Wright, V.P., 2012. Lacustrine carbonates in rift settings: the interaction of volcanic and microbial processes on carbonate deposition. Geological Society, London, Special Publications, 370 (1), 39-47. https://doi.org/ $10.1144 /$ sp370 